\title{
PENGARUH KOMPETENSI PEGAWAI DAN DISIPLIN KERJA TERHADAP EFEKTIVITAS KERJA PEGAWAI PADA KANTOR IMIGRASI KELAS I JAKARTA UTARA
}

\author{
Zaman Zaini $^{1}$, Rida Agustian ${ }^{2}$ \\ Institut Ilmu Sosial dan Manajemen STIAMI \\ zamanzaini@stiami.ac.id ${ }^{1}$, ridaagustian@gmail.com ${ }^{2}$
}

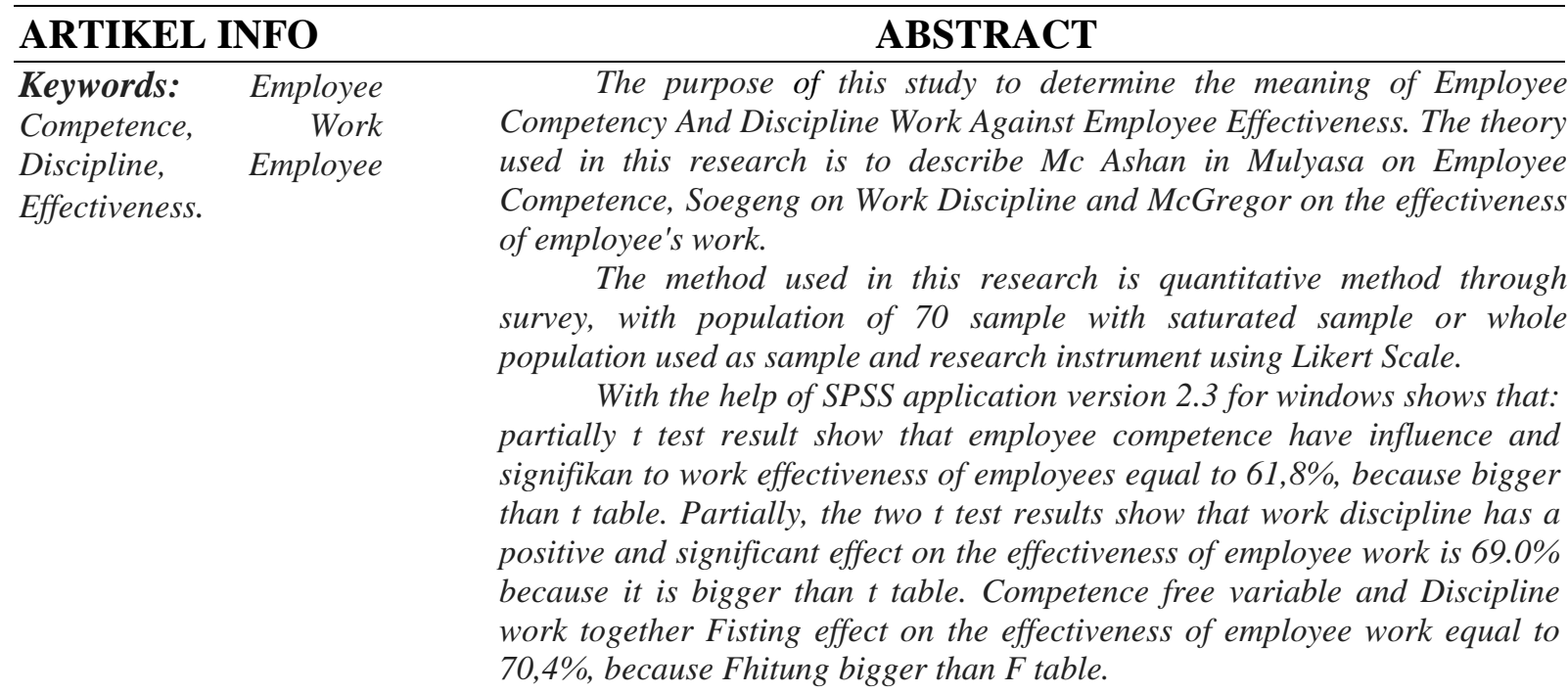

\section{PENDAHULUAN}

Perwujudan pemerintahan yang baik dan bersih (good and clean governances) merupakan tuntutan sekaligus kebutuhan yang mutlak untuk mencapai tujuan pembangunan nasional. Hal ini karena salah satu kendala paling besar yang menghambat kemajuan ekonomi dan pembangunan diantaranya adalah masih maraknya praktek penyalahgunaan kekuasaan dan keuangan, sehingga dana dan sumber daya yang ada tidak bisa dimanfaatkan secara optimal bagi kesejahteraan masyarakat dan pertumbuhan ekonomi.

Di lingkungan Kantor Imigrasi Kelas I Jakarta Utara, Sumber daya manusia yang memiliki komitmen atas efektifitaskerja turut menentukan pencapaian tujuan organisasi. Komitmen ini harus menjadi dasar bagi setiap individu dalam melaksanakan tugas sehari-hari. Tanpa landasan ini akan terjadi ketidakefektifitasan khususnya dalam mencapai tujuan organisasi. Ketidakefektifitasan dalam suatu organisasi juga merupakan ketidakefektifitasan dari individu masing-masing anggota organisasi, yang dalam melaksanakan fungsinya tidak berdasarkan suatu prosedur kerja yang terstandarisasi, namun lebih kepada kemauan masing-masing pribadi pekerja itu sendiri. Hal ini pada gilirannya menimbulkan kesemrawutan kerja, di mana kesemrawutan ini membawa organisasi ke jalan yang tidak baik atau tidak fokus pada sasaran yang ditetapkan.

Efektifitas kerja merupakan ketepatan pelaksanaan tugas dari seorang pegawai dengan rasa bertanggung jawab, disiplin, kerja sama, dan mencapai tujuan yang telah ditetapkan organisasi. Hal ini berarti bahwa sesuatu target atau sasaran yang telah ditetapkan oleh suatu organisasi dapat tercapai secara memuaskan dengan waktu yang sudah ditetapkan. Efektifitas juga merupakan tolak ukur dalam mencapai suatu pekerjaan, dengan hasil jumlah yang sebesar mungkin dan kualitas prima dan sesuai dengan tuntutan yang dapat memberikan kepuasan kepada setiap orang yang terkait baik pelaksana, pimpinan. Adapun efektivitas kerja pegawai pada kantor Imigrasi Kelas I Jakarta Utara dapat terlihat dalam menyelesaikan tugas dan pekerjaan menyelesaikan pelayanan terhadap masyarakat dalam pembuatan pospor dan dapat terlibat pada tabel 1. sebagai berikut: 


\section{REKAPITULASI PENGELUARAN PASPOR REPUBLIK INDONESIA \\ PADA KANTOR IMIGRASI KELAS I JAKARTA UTARA \\ BULAN JANUARI S/D DESEMBER TAHUN 2016}

\begin{tabular}{|c|c|c|c|c|}
\hline NO. & BULAN & 24-HAL & 48-HAL & E-PASPOR \\
\hline 1 & JANUARI & 0 & 3180 & 1219 \\
\hline 2 & FEBRUARI & 9 & 3504 & 765 \\
\hline 3 & MARET & 0 & 4195 & 1150 \\
\hline 4 & APRIL & 2 & 3572 & 1379 \\
\hline 5 & MEI & 3 & 3251 & 1518 \\
\hline 6 & JUNI & 3 & 3085 & 1560 \\
\hline 7 & JULI & 2 & 2278 & 1369 \\
\hline 8 & AGUSTUS & 4 & 3061 & 1217 \\
\hline 9 & SEPTEMBER & 3 & 2557 & 1272 \\
\hline 10 & OKTOBER & 22 & 3470 & 1578 \\
\hline 11 & NOVEMBER & 22 & 3663 & 1384 \\
\hline 12 & DESEMBER & 13 & 3063 & 1458 \\
\hline & TOTAL & 83 & 38879 & 15869 \\
\hline \multicolumn{5}{|c|}{ Keterangan : } \\
\hline \multicolumn{2}{|c|}{$24 \mathrm{HAL}$} & \multicolumn{3}{|c|}{ PASPOR 24 Halaman } \\
\hline \multicolumn{2}{|c|}{$48 \mathrm{HAL}$} & \multicolumn{3}{|c|}{ PASPOR 48 Halaman } \\
\hline \multicolumn{2}{|c|}{ E-PASPOR } & \multicolumn{3}{|c|}{ PASPOR Electronic } \\
\hline
\end{tabular}

Dilingkungan Kantor Imigrasi Kelas I Jakarta Utara ternyata belum semua tujuan organisasi dapat tercapai sesuai sasaran atau belum efektif, Selain itu, berdasarkan fenomena pegawai yang ada diketahui belum semua pegawai memiliki komitmen yang kuat terhadap efektifitas kerja. Hal ini terlihat dari beberapa pegawai memiliki kemampuan yang lemah dalam melaksanakan perumusan kebijakan pengawasan intern, pelaksanaan pengawasan intern terhadap kinerja dan keuangan melalui audit, evaluasi, pemantauan dan kegiatan pengawasan, penyusunan laporan hasil pengawasan di lingkungan kerja Imigrasi, serta beberapa pekerjaan yang tidak dapat diselesaikan sesuai target waktu. Berdasarkan kondisi tersebut maka efektifitas kerja pegawai pada Kantor Imigrasi Kelas I Jakarta Utara perlu ditingkatkan dalam rangka mencapai sasaran kerja pada Kantor Imigrasi Kelas I Jakarta Utara.

Efektifitas kerja pegawai dapat dipengaruhi oleh beberapa faktor seperti kepemimpinan, iklim organisasi, kompetensi pegawai, motivasi kerja, profesionalitas, disiplin kerja, koordinasi, budaya organisasi, pelatihan, dan sebagainya. Diantara faktor-faktor tersebut diduga kompetensi pegawai dan disipin kerja cukup dominan mempengaruhi efektifitas kerja pegawai pada Kantor Imigrasi Kelas I Jakarta Utara.

Kompetensi pegawai pada Kantor Imigrasi Kelas I Jakarta Utara merupakan pengetahuan, sikap dan keterampilan yang ada pada diri pegawai untuk unjuk kerja dalam menyiapkan perumusan kebijakan pengawasan intern di lingkungan Kantor Imigrasi, Efektifitas kerja pegawai juga dapat dipengaruhi oleh disiplin kerja. Disiplin kerja merupakan suatu sikap dan perilaku yang berniat untuk 
jujur dan mentaati peraturan organisasi, yang didasarkan atas kesadaran diri untuk menyesuaikan dengan peraturan organisasi. Disiplin kerja merupakan hal yang penting dalam mencapai tujuan organisasi. Rasa tanggungjawab seseorang terhadap tugas-tugas yang diberikan dapat dicerminkan melalui disiplin kerjanya. Disiplin kerja juga merupakan pengikat pegawai dalam suatu organisasi. Disiplin kerja pegawai pada Kantor Imigrasi Kelas I Jakarta Utara merupakan suatu sikap dan perilaku ketaatan terhadap peraturan yang berlaku, siap menerima sanksi jika melanggar tugas dan wewenang, serta dilaksanakan dengan rasa senang hati. Disiplin pegawai tersebut dapat diidentifikasi sebagai suatu sikap menghormati, patuh dan taat terhadap peraturan-peraturan yang berlaku, baik tertulis maupun yang tidak tertulis, serta sanggup menjalankannya dan tidak mengelak untuk menerima sanksi jika pegawai melanggar tugas dan wewenang yang telah diberikan kepadanya.

Berdasarkan observasi awal, kompetensi pegawai yang belum memuaskan, dikarenakan kurangnya kemampunan atau skill yang dimiliki oleh pegawai, kurangnya pengetahuan serta keterampilan pegawai dalam melaksanakan pekerjaannya belum sesuai dengan tufoksinya, kadangkala tugas-tugas rutin sering tertunda karena adanya tugas-tugas lain yang datangnya dari pemimpin yang lebih tinggi sehingga pekerjaan menumpuk, dalam hal disiplin kerja pegawai pada Kantor Imigrasi kelas I Jakarta Utara masih perlu ditingkatkan, hal ini terlihat dari kurangnya disiplin pegawai yang datang ke kantor sering terlambat, jam kantor tidak dimanfaatkan dengan sebaik-baiknya kadang kala ada pegawai keluar kantor tidak seijin kepala bagian masing-masing dan berlama-lama di luar kantor sehingga mengabaikan tugas-tugasnya. Dan jam pulang kantor banyak pegawai yang pulang sebelum waktunya, sehingga efektivitas kerja pegawai tidak dapat berjalan sesuai harapan dan tujuan organisasi pada Kantor Imigrasi Kelas I Jakarta Utara.

\section{KAJIAN LITERATUR}

\section{Kompetensi Pegawai}

Dalam terminologi yang berlaku umum, istilah kompetensi berasal dari bahasa Inggris, yaitu competence. Menurut Fullan (2006: 188) inti dari pengertian kompetensi lebih cenderung pada apa yang dapat dilakukan seseorang dari pada apa yang mereka ketahui. Kompetensi merupakan kemampuan yang dimiliki oleh seseorang yang nampak pada sikapnya yang sesuai dengan kebutuhan kerja. Kompetensi sebagai input adalah kapasitas atau potensi yang muncul di dalam diri seseorang untuk menyelesaikan suatu masalah dengan baik. Input kompetensi dapat menggunakan dua bentuk. Pertama, kemampuan yang diperoleh dari belajar, latihan dan pengalaman. Kedua, kemampuan yang diperoleh dari dalam diri individu yang mempengaruhinya dengan kuat. (Coombe dalam Taufik, 2007:144), Kompetensi Pegawai (X1) Dimensi Kajian: Pengetahuan, Sikap, Keterampilan Sumber : Mc Ashan dalam Mulyasa (2009:41).

\section{Disiplin Kerja}

Pengertian disiplin adalah sebagai sikap mental yang tercermin dalam perbuatan atau tingkah laku perorangan, kelompok atau masyarakat berupa ketaatan (obedience) terhadap peraturan-peraturan atau ketentuan yang ditetapkan organisasi atau pemerintah, etika, norma dan kaidah yang berlaku dalam masyarakat untuk tujuan tertentu. Disiplin juga dapat diartikan sebagai pengendalian diri agar tidak melakukan sesuatu yang bertentangan dengan falsafah dan moral. Disiplin Kerja (X2) Dimensi Kajian: Ketaatan, Kejujuran, Tanggungjawab, Ketegasan Sumber : Soegeng (2009:37).

\section{Efektivitas Kerja Pegawai}

Dalam pengertian teoritis atau praktis, tidak ada persetujuan yang universal menganai apa yang dimaksud dengan kefektifan. Bagaimanapun definisi keefektifan berkaitan dengan pendekatan umum. Apabila ditelusuri maka kefektifan berasal dari kata dasar 'efektif' yang artinya : 1) Ada efeknya (pengaruh, akibatnya, kesannya) sperti : manjur; mujarab; ampuh. 2) Penggunaan metode atau cara, sarana/alat dalam melaksanakan aktivitas sehingga berhasil guna. (Suwarto, 2008: 11).

Denim (2009:99) menyatakan sebagai berikut : Pengertian efektivitas erat dikaitkan dengan tingkat keberhasilan suatu aktivitas, termasuk aktivitas sektor publik. Efektivitas adalah suatu keadaan yang mengandung pengertian mengenai terjadinya sesuatu efek atau akibat yang dikehendaki. Kalau seseorang melakukan suatu perbuatan dengan maksud tertentu yang memang dikehendaki, maka orang itu dikatakan efektif kalau menimbulkan akibat sebagaimana yang dikehendakinya. Efektivitas 
menunjukkan keberhasilan dari segi tercapai tidaknya sasaran yang telah ditetapkan. Jika hasil kegiatan semakin mendekati sasaran, berarti makin tinggi efektivitasnya.

Efektivitas merupakan pemanfaatan sumber daya, sarana dan prasarana dalam jumlah tertentu yang secara sadar ditetapkan sebelumnya untuk menghasilkan sejumlah barang atas jasa kegiatan yang dijalankannya. Menurut Saudi (2007:44) efektivitas adalah perbandingan antara keluaran dengan tujuan. Oleh karena itu suatu tujuan harus jelas dinyatakan secara spesifik dan rinci, sehingga pengukuran efektifitas dapat lebih bermanfaat dan bermaksud, serta berbeda dengan efesiensi.

Efektifitas Kerja Pegawai (Y). Dimensi Kajian: Ketepatan pelaksanaan tugas, Tanggungjawab, Kerjasama, Mencapai tujuan. Sumber : Mc Gregor (2001:112)

\section{METODE PENELITIAN}

Penelitian ini menggunakan lokasi pada Kantor Imigrasi Kelas I Jakarta Utara, alasan mengambil lokasi ini karena masih minimnya riset khususnya pada kompetensi pegawai, disiplin kerja terhadap efektivitas kerja pegawai. dengan harapan adanya perubahan kompetensi pegawai, disiplin kerja yang dapat meningkatkan efektivitas kerja pegawai.

Berdasarkan kerangka konseptual maka variabel-variabel dalam penelitian ini dapat diidentifikasi. Pada penelitian ini penulis menerapkan paradigma penelitian ini berlandaskan filsafat positivistik dimana fenomena dapat diklasifikasikan, relatif tetap dan kongkrit. Penelitian dilakukan dengan menggunakan metode survey dan pendekatan secara kuantitatif karena telah terdapat teori yang mendasari penelitian tesis ini, yakni teori yang menyatakan bahwa Efektivitas kerja pegawai itu dipengaruhi oleh dua faktor, yaitu: Kompetensi pegawai dan Disiplin kerja (Zain; 2003) .

\section{Operasional Variabel Penelitian}

\section{Definisi Konseptual}

1. Kompetensi Pegawai

Kompetensi merupakan sifat dasar yang menunjukkan cara cara berperilaku atau berpikir dalam berbagai pekerjaan dan situasi tertentu dalam kurun waktu yang lama, dengan dimensi : 1) pengetahuan, 2) sikap, 3) keterampilan.

2. Disiplin Kerja

Disiplin kerja adalah kesanggupan seseorang untuk menaati, mematuhi, menghormati dengan tertib peraturan-peraturan atau ketentuan-ketentuan yang berlaku, baik tertulis maupun yang tidak tertulis, dengan dimensi: 1) ketaatan, 2) kejujuran, 3) tanggung jawab, dan 4) ketegasan.

3. Efektivitas Kerja Pegawai

Efektivitas kerja pegawai menunjukan keberhasilan pada tingkat pekerja dari segi tercapai tidaknya sasaran yang telah ditetapkan. Jika hasil kegiatan semakin mendekati sasaran, berarti makin tinggi efektivitasnya, dengan dimensi : 1) ketepatan pelaksanaan tugas; 2) tanggungjawab; 3) kerja sama, dan 4) mencapai tujuan.

Teknik pengumpulan data dengan menggunakan data primer dsan data skunder, untuk teknik sampling dengan menggunakan teknik sampel jenuh karena populasi kurang dari 100, maka populasi/sampelnya di pergunakan semua. Jumlah pupolasi yang terdapat pada Kantor Imigrasi berjumlah 70 orang/responden.

\section{HASIL PENELITIAN DAN PEMBAHASAN}

Hasil penelitian ini merupakan hasil dari olah data mentah penelitian yang berupa data hasil kuisioner yang kemudian diterjemahkan dalam bentuk angka sebelum dianalisis. Data diperoleh dari responden yang menjadi sampel dari populasi yang ada pada Kantor Imigrasi Kelas I Jakarta Utara. Data tersebut diperoleh dengan cara menyebarkan kuisioner di lokasi penelitian yaitu Kantor Imigrasi Kelas I Jakarta Utara yang kemudian diambil kembali secara kolektif secara bertahap.

Berdasarakan hasil pengolahan data dengan menggunakan SPSS Versi 23 For Windows, Pengaruh Kompetensi pegawai terhadap efektivitas kerja pegawai dan berdasarkan table summary, nilai koefisien korelasi R sebesar 0.786 atau korelasi antara Kompetensi pegawai dengan Efektifitas Kerja Pegawai pada Kantor Imigrasi Kelas I Jakarta Utara tergolong cukup tinggi. Koefisien determinasi (R square) sebesar 0,618, artinya variable Kompetensi pegawai mempengaruhi Efektifitas 
Kerja Pegawai pada Kantor Imigrasi Kelas I Jakarta utara sebesar 0,618 atau 61,8 \%. Dan berdasarkan nilai koefisien menunjukan bahwa t hitung $>t$ tabel yaitu 10,848 $>1.671$ sehingga disimpulkan secara parsial Kompetensi pegawai memiliki hubungan yang positif dan signifikan terhadap Efektifitas Kerja Pegawai pada Kantor Imigrasi Kelas I Jakarta Pusat.

Berdasarkan table summary, nilai koefisien korelasi $\mathrm{R}$ sebesar 0,830 atau korelasi antara Disiplin Kerja dengan Efektifitas Kerja Pegawai tergolong cukup tinggi. Koefisien determinasi (R square) sebesar 0,690, artinya variabel Disiplin Kerja mempengaruhi Efektifitas Kerja Pegawai sebesar 0,690 atau (69,0 \%). Dan berdasarkan nilai koefisien menunjukan bahwa t hitung $>\mathrm{t}$ tabel yaitu 12,290 > 1.671 sehingga disimpulkan secara parsial Disiplin Kerja memiliki hubungan yang positif dan signifikan terhadap Efektifitas Kerja Pegawai pada Kantor Imigrasi Kelas I Jakarta Utara.

Berdasarkan table summary di atas, nilai koefisien korelasi R sebesar 0.839 atau korelasi antara Disiplin Kerja dengan Efektifitas Kerja Pegawai tergolong tinggi. Koefisien determinasi (R square) sebesar 0,704 artinya variabel Kompetensi pegawai dan Disiplin Kerja secara bersama-sama mempengaruhi Efektifitas Kerja Pegawai sebesar 0.740 atau (70,4 \%). Berdasarkan Tabel ANOVA, diperoleh nilai $F$ sebesar 79,864, yang artinya F hitung > F yaitu 79,864 > 3.11 sehingga dapat disimpulkan bawah Kompetensi pegawai dan Disiplin Kerja secara bersama-sama berpengaruh positif dan signifikan terhadap Efektifitas Kerja Pegawai pada Kantor Imigrasi Kelas I Jakarta Utara.

\section{KESIMPULAN DAN SARAN}

\section{Kesimpulan}

Berdasarkan hasil penelitian dan pembahasan mengenai pengaruh kompetensi pegawai dan disiplin kerja terhadap efektivitas kerja pegawai pada Kantor Imigrasi Kelas I Jakarta utara maka kesimpulan dari penelitian ini adalah sebagai berikut: 1. Terdapat pengaruh yang signifikan kompetensi pegawai terhadap efektivitas kerja pegawai pada Kantor Imigrasi Kelas I Jakarta utara. Semakin baik kondisi kompetensi pegawai maka akan semakin meningkat pula efektivitas kerja pegawai pada Kantor Imigrasi Kelas I Jakarta utara. Besarnya pengaruh kompetensi pegawai terhadap efektivitas kerja pegawai pada Kantor Imigrasi Kelas I Jakarta utara sebesar 61,8 \%. 2. Terdapat pengaruh yang signifikan disiplin kerja terhadap efektivitas kerja pegawai pada Kantor Imigrasi Kelas I Jakarta utara.

Semakin baik penerapan disiplin kerja maka akan semakin meningkat pula efektivitas kerja pegawai pada Kantor Imigrasi Kelas I Jakarta utara. Besarnya pengaruh disiplin kerja terhadap efektivitas kerja pegawai pada Kantor Imigrasi Kelas I Jakarta utara sebesar 69,0 \%. 3. Terdapat pengaruh yang positif dan signifikan kompetensi pegawai dan disiplin kerja secara bersama-sama terhadap efektivitas kerja pegawai pada Kantor Imigrasi Kelas I Jakarta utara. Semakin baik kondisi kompetensi pegawai dan penerapan disiplin kerja secara bersama-sama maka akan semakin meningkat pula efektivitas kerja pegawai pada Kantor Imigrasi Kelas I Jakarta utara. Besarnya pengaruh kompetensi pegawai dan disiplin kerja secara simultan terhadap efektivitas kerja pegawai pada Kantor Imigrasi Kelas I Jakarta utara sebesar 70,4\%.

\section{Saran}

Saran untuk Kepala kantor Imigrasi Kelas I jakarta Utara, Agar membuat suatu kebijakan baru yang mana guna memacu efektifitas kerja pegawai serta mendisiplinkan semua pegawai untuk bekerja lebih semangat serta adanya peningkatan pada tugas dan fungsinya masing-masing pegawai melalui: Memberikan Kesempatan terhadap pegawai yang berprestasi untuk mendapatkan jenjang pendidikan yang lebih tinggi, Membuat peraturan tentang kedisiplinan agar waktu atau jam kerja lebih efisien dan efektif,

Memberikan kesempatan pada pegawai untuk mengitkuti pelatihan atau seminar dan lokakarya. Berdasarkan hasil penelitian diketahui kompetensi pegawai pengaruhnya lebih kecil dibandingkan disiplin terhadap efektivitas kerja pegawai pada Kantor Imigrasi Kelas I Jakarta utara, maka perlu upaya-upaya yang konkrit dalam meningkatkan aspek kompetensi pegawai. Pembenahan kompetensi pegawai dilakukan melalui:

1. Pegawai secara berkala mendapatkan kesempatan untuk mengikuti pelatihan, Pegawai mengikuti seminar, lokakarya serta kegiatan lainnya yang terkait dengan peningkatan 
pemahaman tugas-tugas di kantor, Pegawai mendapatkan kesempatan untuk meningkatkan jenjang penddikan formal, dan sebagainya.

2. Pembenahan disiplin kerja dilakukan melalui peningkatan pemahaman pegawai mengenai disiplin kerja serta pemberian sanksi yang lebih tegas bagi pegawai yang melanggar serta memberikan reward bagi yang berdisiplin baik.

3. Disarankan adanya penelitian lebih lanjut mengenai faktor-faktor lain selain kompetensi pegawai dan disiplin kerja pengaruhnya terhadap efektivitas kerja pegawai pada Kantor Imigrasi Kelas I Jakarta utara.

4. Hasil penelitian ini menjadi landasan untuk mengambil kebijakan mengenai peningkatan efektivitas kerja pegawai pada Kantor Imigrasi Kelas I Jakarta utara.

\section{DAFTAR PUSTAKA}

Amilin dan R. Dewi. "Pengaruh Komitmen Organisasi Terhadap Kepuasan Kerja Dengan Role Stress Sebagai Variabel Moderating", JAAI Vol 12 No 1, 2008.

Anggraeni, Nenny. 2008. Pengaruh Kemampuan Dan Motivasi Terhadap Kinerja Pegawai Pada Sekolah Tinggi Seni Indonesia (Stsi) Bandung. ISSN 1412- 565X.

Arifah, Nurul. 2012. Pengaruh Independensi Auditor, Komitmen Organisasi Dan Gaya Kepemimpinan Terhadap Kinerja Auditor. Tesis Universitas Hasanuddin Makassar.

Awat, J. Napa, 1995, Metode Statistik dan Ekonometri, Liberty, Yogyakarta

Awaluddin, Murtiadi. 2013. Pengaruh Independensi dan Kompetensi Auditor Terhadap Kepuasan Kerja dan Kinerja Auditor Inspektorat Kota Makasar. ASSETS Volume 3 nomer 2 tahun 2013.

Azwar, S. 2001. Reliabilitas dan Validitas. Yogyakarta :Pustaka Pelajar.

Bagong, S Sutinah. 2006. Metode Penelitian Sosial. Jakarta : Kencana

Efendy, M. Taufiq. 2010. Pengaruh Kompetensi, Independensi dan MotivasiTerhadap Kualitas Audit Aparat Inspektorat Dalam Pengawasan Keuangan Daerah. Tesis.Universitas Diponegoro.

Elita. 2012. Pengaruh Independensi, Gaya Kepemimpinan, Komitmen Organisasi dan Pemahaman Good Governance Terhadap Kinerja Auditor Pemerintah (Studi Empiris Pada Auditor Pemerintah BPK-RI Perwakilan Provinsi D.I Yogyakarta). Tesis Universitas Islam Indonesia.

Ghozali, Imam. 2005. Aplikasi Analisis Multivatiate dengan Program SPSS. Semarang: Badan Penerbit Universitas Diponegoro.

Helmi F. Avin. 1996. Disiplin Kerja. Yogyakarta: UGM.

Hidayat. 1986. Teori Efektifitas Dalam Kinerja Karyawan. Gajah Mada University Press. Yogyakarta.

Indriantoro, Nur dan S. Bambang. 2002. Metodologi Penelitian Untuk Akuntansi \& Manajemen. Edisi Pertama. BPFE: Yogyakarta.

Istiqomah, I. Wahyuni. 2003. Pengaruh Kepuasan Kerja, Komitmen Organisasional dan Komitmen Profesional Terhadap Keinginan Berpindah Auditor Pada Kantor Akuntan Publik (Kap) di Jawa Timur. Staf Pengajar STIE Al-Anwar Mojokerto.

Kurniawan, M. R. Nur. 2011. Pengaruh Komitmen Organisasi, Budaya Organisasi, Dan Kepuasan Kerja Terhadap Kinerja Organisasi Publik (Studi Pada Pemerintah Daerah Kabupaten Demak). Tesis. Universitas Diponegoro Semarang.

Marganingsih, Arywarti dan Martani, Dwi. 2009. Analisis Variabel Anteseden Perilaku Auditor Internal Dan Konsekuensinya Terhadap Kinerja: Studi Empiris Pada Auditor Di Lingkungan Aparat Pengawasan Intern Pemerintah - Lembaga Pemerintah Non Departemen. Simposium Nasional Akuntansi XII Padang 2009.

Mc. Ashan, H.H (2009), Competency-based education and Behavioral Objectives, New Jersey, Educational Technology Publication, Inc. 
Mulyasa E (2009). Kurikulum Berbasis Kompetensi : Konsep, Karakteristik, dan Implementasi. Bandung : PT Remaja Rosdakarya.

Mulyawan, Budi. 2009. Pengaruh Pelaksanaan Good Governance Terahadap Kinerja Organisasi (Studi Pada Dinas esejahteraan Sosial Kota Palembang). Tesis Universitas Sumatera Utara.

Prajitno, Sugiarto 2012. Faktor Faktor Yang Mempengaruhi Kinerja Akuntan Publik Di Jakarta. Jurnal Bisnis dan Akuntansi, Vol. 14, No. 3, Desember 2012, Hlm 181-192.

Pratama, B. putra. 2012. Analisis Pengaruh Independensi, Gaya Kepemimpinan, Komitmen Organisasi dan Pemahaman Good Governance Terhadap Kinerja Auditor Pemerintah (Studi PadaAuditor Pemerintah di BPKP Yogyakarta). Skripsi. Universitas Muhammadiyah Yogyakarta.

Prawirosentono, 1999.Teori Efektifitas. PT. Graha Gresik. Depok.

Riduwan. (2003) Skala Pengukuran Variabel-Variabel Penelitian. Bandung: Alfabeta

Ritonga, H. Rahmansyah. 2013. Optimalisai Audit Kinerja Instansi Pemerintah. http://sumut.kemenag.go.id.

Sapariyah, rina ani. 2011. Pengaruh Good Governance dan Independensi Auditor Terhadap Kinerja Auditor Dan Komitmen Organisasi. STIE AUB Surakarta.

Sugiyono, 2011. Metoda Penelitian Administrasi, Cetakan Kedelapan, Alfabeta, Bandung.

Sudrajat, Akhmad. 2008. Sekilas Tentang Disiplin Kerja.Diakses dihttp://www.google. disiplinkerja.com.

Soegeng. P (2009). Disiplin Kerja. Jakarta : PT. Pradnya Paramita.

Trisnaningsih, Sri. 2007. Independensi Auditor Dan Komitmen Organisasi Sebagai Mediasi Pengaruh Pemahaman Good Governance, Gaya Kepemimpinan Dan Budaya Organisasi Terhadap Kinerja Auditor. Simposium Nasional Akuntansi X Makasar 2007.

Wati, elya. Lismawati dan Aprilla, Nila. 2010. Pengaruh Independensi Auditor, Gaya kepemimpinan, Komitmen Organisasi,dan Pemahaman Good Governance (StudiPada Auditor Pemerintah di BPKP Perwakilan Bengkulu). Simposium Nasional Akuntansi XIII Purworkerto 2010.

Widhi, Saputro Nugroho, 2014. Pengaruh Independensi, Gaya Kepemimpinan, Komitmen Organisasi dan Pemahaman Good Governance Terhadap Kinerja Auditor Pemerintah (Studi Empiris Pada Kantor BPKP Perwailan Jawa Tengah). Skripsi. Universitas Muhammadiyah Surakarta.

Winarno, Surakhmad, 1994. Pengantar Penelitian Ilmiah. Bandung : Tarsito.

Yuskar dan Devisia, Selly. 2011. Pengaruh Independensi Auditor, Komitmen Organisasi,Pemahaman Good Governance, Integritas

Auditor, Budaya Organisasi, Dan Etos Kerja Terhadap Kinerja Auditor (Studi Empiris pada Kantor Akuntan Publik Big Four yang Berafiliasi di Indonesia Tahun 2011).

Simposium Nasional Akuntansi X IV Aceh 2011. 